\title{
Metabolic Syndrome Parameters, Determinants, and Biomarkers in Adult Survivors of Childhood Cancer: Protocol for the Dutch Childhood Cancer Survivor Study on Metabolic Syndrome (Dutch LATER METS)
}

Vincent Pluimakers ${ }^{1}$, MD; Marta Fiocco ${ }^{1,2,3}, \mathrm{PhD}$; Jenneke van Atteveld ${ }^{1}$, MD; Monique Hobbelink ${ }^{4}$, MD; Dorine Bresters $^{1}, \mathrm{MD}, \mathrm{PhD}$; Eline Van Dulmen-den Broeder ${ }^{1,5}, \mathrm{PhD}$; Margriet Van der Heiden-van der Loo ${ }^{6}, \mathrm{PhD}$; Geert O Janssens $^{1,4}$, MD, PhD; Leontien Kremer ${ }^{1,5}$, MD; Jacqueline Loonen ${ }^{7}$, MD, PhD; Marloes Louwerens ${ }^{2}$, MD; Helena Van der Pal ${ }^{1}$, MD, PhD; Cécile Ronckers ${ }^{1,5,8}$, PhD; Hanneke Van Santen ${ }^{1,9}$, MD, PhD; Birgitta Versluys ${ }^{1,9}$, MD, PhD; Andrica De Vries ${ }^{1,10}$, MD, PhD; Marry Van den Heuvel-Eibrink ${ }^{1}$, MD; Sebastian Neggers ${ }^{1,11}$, MD, PhD

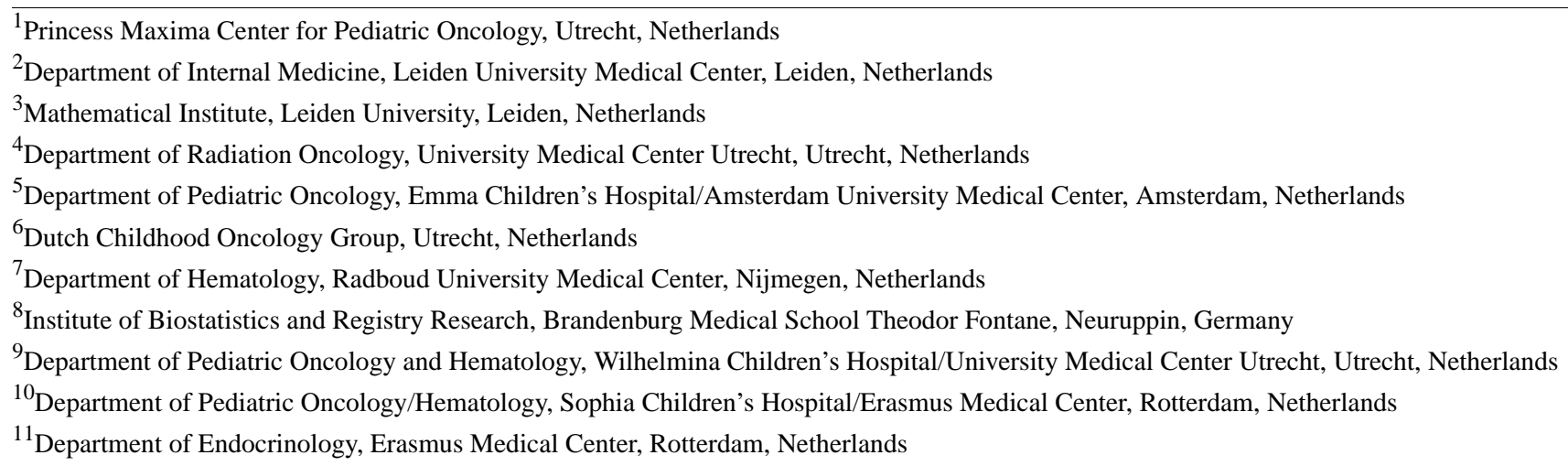

Corresponding Author:

Vincent Pluimakers, MD

Princess Maxima Center for Pediatric Oncology

Heidelberglaan 25

Utrecht, 3584CS

Netherlands

Phone: 31613348669

Email: v.g.pluimakers@prinsesmaximacentrum.nl

\begin{abstract}
Background: Potential late effects of treatment for childhood cancer include adiposity, insulin resistance, dyslipidemia, and hypertension. These risk factors cluster together as metabolic syndrome and increase the risk for development of diabetes mellitus and cardio- and cerebrovascular disease. Knowledge on risk factors, timely diagnosis, and preventive strategies is of importance to prevent cardio- and cerebrovascular complications and improve quality of life. Currently, no national cohort studies on the prevalence and determinants of metabolic syndrome in childhood cancer survivors, including biomarkers and genetic predisposition, are available.

Objective: The objectives of the Dutch LATER METS study are to assess 1) the prevalence and risk factors of metabolic syndrome and its separate components, and 2) the potential diagnostic and predictive value of additional biomarkers for surveillance of metabolic syndrome in the national cohort of adult long-term survivors of childhood cancer.

Methods: This is a cross-sectional study based on recruitment of all survivors treated in the Netherlands between 1963 and 2002. Metabolic syndrome will be classified according to the definitions of the third Adult Treatment Panel Report of the National Cholesterol Education Program as well as the Joint Interim Statement and compared to reference data. Dual-energy x-ray absorptiometry scans were performed to assess body composition in more detail. The effect of patient characteristics, previous treatment, and genetic variation on the risk of metabolic syndrome will be assessed. The diagnostic and predictive value of novel biomarkers will be tested.
\end{abstract}


Results: Patient accrual started in 2016 and lasted until April 2020. A total of 2380 survivors from 7 pediatric oncology hospitals have participated. From July 2020, biomarker testing, single nucleotide polymorphism analysis, and data analysis will be performed.

Conclusions: The Dutch LATER METS study will provide knowledge on clinical and genetic determinants of metabolic syndrome and the diagnostic value of biomarkers in childhood cancer survivors. The results of this study will be used to optimize surveillance guidelines for metabolic syndrome in survivors based on enhanced risk stratification and screening strategies. This will improve diagnosis of metabolic syndrome and prevent complications.

International Registered Report Identifier (IRRID)： DERR1-10.2196/21256

(JMIR Res Protoc 2021;10(1):e21256) doi: 10.2196/21256

\section{KEYWORDS}

metabolic syndrome; childhood cancer survivor; Dutch Childhood Cancer Survivor Study; methodology; Dutch LATER METS

\section{Introduction}

Due to increasing survival of patients with childhood cancer, late side effects have become more prominent. Potential late effects include adiposity, insulin resistance, dyslipidemia, and hypertension, which cluster together as metabolic syndrome. Metabolic syndrome is associated with a higher risk of diabetes mellitus, as well as cardio- and cerebrovascular morbidity and mortality later in life [1-3]. The separate components are in themselves risk factors for diabetes and cardiovascular disease but, when coexisting, the components can aggravate each other, leading to an even higher risk of diabetes and cardiovascular disease $[4,5]$.

Studies in childhood cancer survivors have reported a prevalence of metabolic syndrome of over $30 \%$ after 25 years follow-up, substantially higher compared to age- and sex-matched controls (odds ratio 1.76) [6,7]. This apparent risk difference for metabolic syndrome further increases the elevated risks for cardiovascular outcomes and endothelial damage from anthracyclines, alkylating agents, and irradiation $[8,9]$. Consequently, the mortality due to coronary and cerebrovascular disease in long-term survivors is up to 12.7 times higher than in the general population [10-13]. The fact that metabolic syndrome can be subclinical for many years emphasizes the need for timely identification of metabolic syndrome in survivors and early intervention strategies. Lifestyle and diet advice, exercise, and medication may prevent the development of diabetes and cardio- and cerebrovascular disease, improving survival rates and quality of life.

Several underlying conditions have been reported to increase the risk for (components of) metabolic syndrome in survivors: growth hormone deficiency, pancreatic beta cell dysfunction, hypogonadism, hypothyroidism, and altered body composition with increased intra-abdominal fat [14-19]. Hence, an increased risk of metabolic syndrome might be associated with treatment for a brain tumor, treatment with radiotherapy, intensive chemotherapy, nephrectomy, adrenalectomy, or stem cell transplantation [7,16,20-32]. The effects of other potentially harmful treatments, for example corticosteroids, and patient-related factors such as sex, age, body mass index at diagnosis, and lifestyle, are still not clear [3]. Also, heterogeneity in incidence of metabolic syndrome among homogeneously treated survivors suggests a role of genetic susceptibility [33,34]. A few studies using candidate gene approaches [24,35] as well as one genome-wide association study [36] have identified genetic variants that might be associated with development of metabolic syndrome and its components in survivors. Results based on these studies have not yet been replicated or functionally validated.

Multiple definitions of metabolic syndrome have been developed over the past years. The two most commonly used are those of the third Adult Treatment Panel Report of the National Cholesterol Education Program [37] and the Joint Interim Statement of the International Diabetes Federation; National Heart, Lung, and Blood Institute; and the American Heart Association [38]. Both definitions overlap largely but they differ in waist circumference cut-off point (Table 1). Apart from the 4 components, pro-inflammatory and prothrombotic markers have been reported to be relevant biomarkers of metabolic syndrome, as has hyperuricemia [39,40].

Adequate assessment of metabolic syndrome in survivors using the National Cholesterol Education Program and Joint Interim Statement definitions has specific challenges, particularly after abdominal radiotherapy. It has been shown that body mass index and waist circumference underestimate adiposity due to deformation of spine, muscles, and fat, particularly in past treatment eras when higher radiotherapy doses and larger fields were used [21,41,42]. Similarly, adiposity can be disguised due to sarcopenic obesity after stem cell transplantation $[43,44]$. Body composition can be more reliably measured by dual-energy $\mathrm{x}$-ray absorptiometry, but this is time consuming and expensive to be implemented for standard follow-up of all survivors. Serum biomarkers may be more cost-effective surrogate markers for metabolic syndrome. In smaller survivor cohorts and in the general population, biomarkers other than triglycerides and high-density lipoprotein cholesterol that have been proposed as predictors of metabolic syndrome include low-density lipoprotein, apolipoprotein-B, leptin, adiponectin, uric acid, and C-reactive protein [39,45-50].

So far, large studies on clinically diagnosed metabolic syndrome in survivors are scarce. Two large multicenter cohort studies with clinically diagnosed metabolic syndrome are the American St. Jude Lifetime (SJLIFE, all types of childhood cancer) [6,7] and the French Leucémies de l'Enfant et l'Adolescent (leukemia) $[31,51,52]$ studies. Other studies have yielded heterogeneous and sometimes conflicting results and can be difficult to compare. This may be due to metabolic syndrome components being analyzed only separately, or due to small patient cohorts, 
a questionnaire based or retrospective design, insufficient treatment data (eg, only childhood cancer diagnosis is known, not treatment), and short follow-up (metabolic syndrome risk increases continuously with age, so a follow-up of 10-20 years likely underestimates this) [22,32,53-55]. In addition, comparison of study outcomes can be difficult due to the use of different classifications. Currently, no studies in national cohorts on prevalence and determinants of metabolic syndrome in childhood cancer survivors, including biomarkers and genetic predisposition to metabolic syndrome, are available.

Here we describe the methodology of the Dutch LATER METS study in the adult cohort of survivors treated between 1963 and 2002. This nationwide study assesses metabolic syndrome prevalence, clinical and genetic risk factors, and the diagnostic and predictive value of additional biomarkers. The results of this study will be used to identify survivors at risk and to optimize surveillance guidelines.

Table 1. NCEP-ATP III ${ }^{\mathrm{a}}$ and JIS ${ }^{\mathrm{b}}$ classifications of metabolic syndrome, and alternative classification with adiposity measured by dual-energy x-ray absorptiometry scan.

\begin{tabular}{|c|c|c|c|c|}
\hline $\begin{array}{l}\text { Required for diagnosis } \\
(\geq 3)\end{array}$ & Measurement & NCEP-ATP III & JIS & $\begin{array}{l}\text { Alternative with dual-energy } x- \\
\text { ray absorptiometry scan }\end{array}$ \\
\hline Adiposity & Waist circumference $(\mathrm{cm})$ & $>102^{\mathrm{c}} / 88^{\mathrm{d}}$ & $\geq 94^{\mathrm{c}} / 80^{\mathrm{d} \mathrm{e}}$, & Body fat Z-score >2 \\
\hline Insulin resistance & Fasting glucose $(\mathrm{mmol} / \mathrm{L})$ & $\geq 5.5$ or treatment & $\geq 5.5$ or treatment & $\geq 5.5$ or treatment \\
\hline \multirow[t]{2}{*}{ Dyslipidemia } & Triglycerides $(\mathrm{mmol} / \mathrm{L})$ & $\geq 1.7$ or treatment & $\geq 1.7$ or treatment & $\geq 1.7$ or treatment \\
\hline & $\begin{array}{l}\text { High-density lipoprotein cholesterol } \\
(\mathrm{mmol} / \mathrm{L})\end{array}$ & $\begin{array}{l}<1.0^{\mathrm{c}} / 1.3^{\mathrm{d}} \text { or treat- } \\
\text { ment }\end{array}$ & $\begin{array}{l}<1.0^{\mathrm{c}} / 1.3^{\mathrm{d}} \text { or treat- } \\
\text { ment }\end{array}$ & $<1.0^{\mathrm{c}} / 1.3^{\mathrm{d}}$ or treatment \\
\hline Hypertension & Blood pressure $(\mathrm{mmHg})$ & $\geq 130 / 85$ or treatment & $\geq 130 / 85$ or treatment & $\geq 130 / 85$ or treatment \\
\hline
\end{tabular}

${ }^{\mathrm{a}}$ NCEP-ATP III = National Cholesterol Education Program Adult Treatment Panel III.

${ }^{\mathrm{b}} \mathrm{JIS}=$ Joint Interim Statement of International Diabetes Federation; National Heart, Lung, and Blood Institute; and the American Heart Association. ${ }^{\mathrm{c}}$ Men.

${ }^{\mathrm{d}}$ Women.

${ }^{\mathrm{e}}$ Cut-off for Caucasian population.

\section{Methods}

\section{Objectives}

The objectives of this study are to assess 1) the prevalence and risk factors (patient characteristics, previous treatment, and genetic variation) of metabolic syndrome and its separate components, compared to reference data, and 2) the potential diagnostic and predictive value of novel biomarkers for surveillance of metabolic syndrome in the national cohort of adult long-term survivors of childhood cancer.

\section{Study Population and Design}

The Dutch LATER METS study is part of the nationwide Dutch LATER study (Figure 1). This study started accrual in all 7 pediatric oncology centers in the Netherlands in 2016, thereby inviting the national cohort of all survivors treated in these hospitals between 1963 and 2002 to participate. Survivors were identified from registries of children with newly diagnosed cancer that are maintained in each of the 7 pediatric oncology centers in the Netherlands. This study merged the available information to create a specific childhood cancer survivors registry containing all registered survivors. Dependent on completeness of the sources in the centers, the starting year varied from 1963 to 1977 . The LATER METS study was approved by the Medical Research Ethics Committee of the Amsterdam University Medical Center (registered at toetsingonline.nl, NL32117.018.10).

In the Dutch LATER study, data from 15 substudies of late effects were collected, including cardiotoxicity, bone density, frailty, growth hormone deficiency, renal toxicity, fatigue, and psychological late effects. Individuals who survived at least 5 years after diagnosis of histologically confirmed malignancies (as defined in the 3rd edition of the International Classification of Childhood Cancer [56]) or Langerhans cell histiocytosis, were treated with chemotherapy or radiotherapy, and were between 0 and 17 years of age at diagnosis were invited. Exclusion criteria were treatment for a malignancy in the past year and living abroad.

For all eligible survivors, prior to the visit of the late-effects clinic, sex; date of birth; date of cancer diagnosis; and detailed data on cancer type and treatment, including chemotherapy regimens and doses, radiotherapy fields and (fractionated) dose, stem cell transplantation and corticosteroid treatments, were collected in a pseudonymized, web-based, central database. This includes primary diagnosis as well as, if present, recurrences and subsequent malignancies.

Subsequently, data collection for all studies was combined with the survivors' regular care visit to the late-effects clinic for the majority of survivors. Before the visit, survivors received information about the study, sent by mail by the study personnel. If they agreed to participate, study data was collected by the treating physician or the study personnel.

The entire cohort, at formation in 2008, contained 6165 eligible survivors. By mail, survivors were provided the option to opt-out of future study participation. For the Dutch LATER study, the cohort was frozen in 2016, leaving 5160 subjects eligible. For the LATER METS study, only adults $(n=4741)$ were invited. 
Inclusion took place until April 2020. Written informed consent was obtained from all study participants.

Figure 1. Overview of the Dutch LATER study cohort and embeddedness of the Dutch LATER METS study cohort within the underlying cohort. Percentages indicate proportion of Dutch LATER cohort $(\mathrm{N}=6165)$.

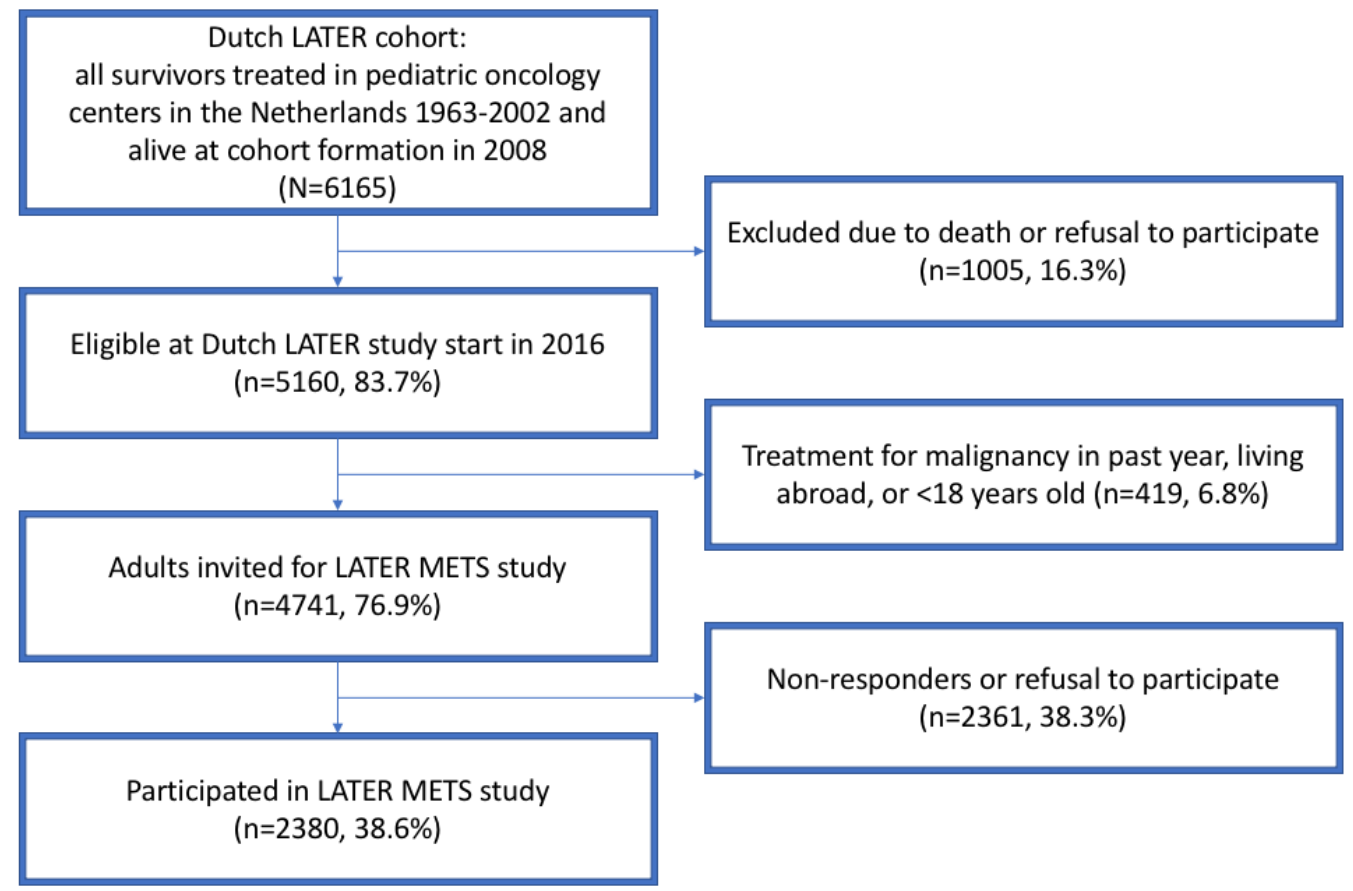

\section{Reference Population}

Normative data from the Dutch Lifelines study cohort will serve as reference population [57]. This is a 3-generation cohort of 167,000 inhabitants (10\%) of the north of the Netherlands, from whom, among other data, the following parameters relevant to our study were collected between 2006 and 2013: age, sex, height, weight, waist and hip circumference, blood pressure, comorbidities, medication use, smoking, physical activity, high-density lipoprotein, triglycerides, glucose, apolipoprotein-B, low-density lipoprotein, total cholesterol, uric acid, and high sensitivity $\mathrm{C}$-reactive protein. We aim to use a subset of this reference cohort as controls that have the same age and sex distribution as our study cohort.

\section{Data Collection}

\section{Data Collected Before Visit of Late-Effects Clinic}

An overview of collected variables is presented in Table 2. In addition to the previously mentioned data, the following variables relevant for the Dutch LATER METS study were extracted from the medical records: height and weight at cancer diagnosis and relevant comorbidities.

\section{Data Collected at Visit of Late-Effects Clinic}

Weight was measured without shoes and with light clothing on an electronic scale to the nearest $0.1 \mathrm{~kg}$. Height was measured without shoes to the nearest centimeter. Body mass index was calculated from weight and height. Waist circumference was measured in the middle between the lower rib and iliac crest to the nearest centimeter. Hip circumference was measured at the greater trochanter to the nearest centimeter. Waist/hip ratio was calculated. Blood pressure was measured after at least 5 minutes rest with an electronic oscillometric meter (the mean of two measurements).

Survivors completed a general health questionnaire, containing questions about comorbidities, current medication use, smoking and alcohol habits, education level, and family history of diabetes mellitus and cardiovascular disease. They also completed the Short Questionnaire to Assess Health enhancing physical activity [58]. Total body dual-energy x-ray absorptiometry scans (Hologic and Lunar types) were used to assess body composition [41]. These measurements include fat percentage and lean body mass. The 6-minutes walking test was performed in a subset of the survivors (those treated in the Sophia children's hospital/Erasmus Medical Center, Rotterdam) as a measure of functional exercise capacity $[59,60]$. 
Table 2. Overview of collected variables.

\begin{tabular}{|c|c|c|c|}
\hline Collection period & Category & Variable & Unit(s) or categories \\
\hline \multirow{23}{*}{$\begin{array}{l}\text { Collected before visit } \\
\text { of late-effects clinic }\end{array}$} & Childhood cancer type and treat- & Primary childhood cancer diagnosis & ICCC $-3^{\mathrm{a}}$ classification \\
\hline & & Treatment protocol & Name and arm \\
\hline & & Chemotherapy, per regimen & $\mathrm{TCD}^{\mathrm{b}}$ \\
\hline & & Radiotherapy field & \\
\hline & & Cranial/craniospinal & TCD, fractions (if applicable) \\
\hline & & Total body & TCD, fractions (if applicable) \\
\hline & & Abdominal & TCD, fractions (if applicable) \\
\hline & & Pancreas involvement & TCD, fractions (if applicable) \\
\hline & & Surgery procedure & \\
\hline & & Autologous stem cell transplantation & Yes / No, conditioning regimen \\
\hline & & Allogeneic stem cell transplantation & Yes / No, conditioning regimen \\
\hline & & Relapse & Yes / No \\
\hline & Patient characteristics & Sex & Male / Female \\
\hline & & Date of birth & Date \\
\hline & & Date of childhood cancer diagnosis & Date \\
\hline & & Date of study measurements (follow-up date) & Date \\
\hline & Medical history & Height at cancer diagnosis & Centimeter \\
\hline & & Weight at cancer diagnosis & Kilogram \\
\hline & & Growth hormone deficiency & Yes / No \\
\hline & & Growth hormone replacement & Yes / No \\
\hline & & Hypothyroidism & Yes / No \\
\hline & & Hypogonadism & Yes / No \\
\hline & & Hypocortisolism with steroid replacement & Yes / No \\
\hline
\end{tabular}




\begin{tabular}{|c|c|c|c|}
\hline Collection period & Category & Variable & Unit(s) or categories \\
\hline \multirow{40}{*}{$\begin{array}{l}\text { Collected at visit of } \\
\text { late-effects clinic }\end{array}$} & \multirow[t]{5}{*}{ Physical examination } & Height & Centimeter \\
\hline & & Weight & Kilogram \\
\hline & & Waist circumference & Centimeter \\
\hline & & Hip circumference & Centimeter \\
\hline & & Blood pressure & $\mathrm{mmHg}$ \\
\hline & \multirow[t]{9}{*}{ General health questionnaire } & \multicolumn{2}{|c|}{ Does the survivor have or has the survivor experienced } \\
\hline & & High cholesterol & Yes / No, age at diagnosis \\
\hline & & Hypertension & Yes / No, age at diagnosis \\
\hline & & Diabetes mellitus & Yes / No, age at diagnosis \\
\hline & & Myocardial infarction & Yes / No, age at diagnosis \\
\hline & & Stroke & Yes / No, age at diagnosis \\
\hline & & Medication use & Type, dose, age at start \\
\hline & & Smoking status & Yes / Former / No \\
\hline & & Cardiovascular disease in family & $\begin{array}{l}\text { Relative, type of disease, age at diag- } \\
\text { nosis }\end{array}$ \\
\hline & $\begin{array}{l}\text { Questionnaire to Assess Health en- } \\
\text { hancing physical activity }\end{array}$ & $N / A^{c}$ & N/A \\
\hline & \multirow{4}{*}{$\begin{array}{l}\text { Dual-energy x-ray absorptiometry } \\
\text { scan }\end{array}$} & Total body fat & Percentage \\
\hline & & Z-score total body fat & Z-score \\
\hline & & Lean body mass & Kilogram per $\mathrm{m}^{2}$ \\
\hline & & Appendicular lean body mass & Kilogram per $\mathrm{m}^{2}$ \\
\hline & 6-minute walking test & N/A & Meter \\
\hline & \multirow{20}{*}{$\begin{array}{l}\text { Data determined from stored sam- } \\
\text { ples }\end{array}$} & \multicolumn{2}{|l|}{ Serum biomarkers } \\
\hline & & High-density lipoprotein & $\mathrm{mmol} / \mathrm{L}$ \\
\hline & & Low-density lipoprotein & $\mathrm{mmol} / \mathrm{L}$ \\
\hline & & Total cholesterol & $\mathrm{mmol} / \mathrm{L}$ \\
\hline & & Apolipoprotein-B & $g / L$ \\
\hline & & Glucose & $\mathrm{mmol} / \mathrm{L}$ \\
\hline & & Insulin & $\mathrm{pmol} / \mathrm{L}$ \\
\hline & & Adiponectin & $\mathrm{ug} / \mathrm{mL}$ \\
\hline & & Leptin & $\mathrm{ng} / \mathrm{mL}$ \\
\hline & & Uric acid & $\mathrm{mmol} / \mathrm{L}$ \\
\hline & & High sensitivity C-reactive protein & $\mathrm{mg} / \mathrm{L}$ \\
\hline & & IL- $6^{\mathrm{d}}$ & $\mathrm{pg} / \mathrm{mL}$ \\
\hline & & $\mathrm{hsTNFa}^{\mathrm{e}}$ & $\mathrm{pg} / \mathrm{mL}$ \\
\hline & & IL- $1^{\mathrm{f}}$ & $\mathrm{pg} / \mathrm{mL}$ \\
\hline & & IGF-1 ${ }^{\mathrm{g}}$ & $\mathrm{ug} / \mathrm{L}$ \\
\hline & & Creatinine & $\mathrm{mg} / \mathrm{mmol}$ \\
\hline & & Urea & $\mathrm{mmol} / \mathrm{L}$ \\
\hline & & $\mathrm{LH}^{\mathrm{h}}$ & $\mathrm{U} / \mathrm{L}$ \\
\hline & & $\mathrm{FSH}^{\mathrm{i}}$ & $\mathrm{U} / \mathrm{L}$ \\
\hline & & $A M H^{j}$ & $\mathrm{ug} / \mathrm{L}$ \\
\hline
\end{tabular}




\begin{tabular}{lccl}
\hline Collection period & Category & Variable & Unit(s) or categories \\
\hline & Estradiol & $\mathrm{pmol} / \mathrm{L}$ \\
& Testosterone & $\mathrm{nmol} / \mathrm{L}$ \\
& DNA from blood/saliva & N/A \\
\hline
\end{tabular}

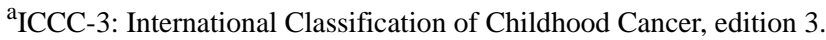

${ }^{\mathrm{b}}$ TCD: total cumulative dose.

${ }^{\mathrm{c}} \mathrm{N} / \mathrm{A}$ : not applicable.

dIL-6: interleukin-6.

ehsTNF: high-sensitivity tumor necrosis factor alpha.

${ }^{\mathrm{f}}$ IL-1: interleukin-1.

gIGF-1: insulin-like growth factor 1.

${ }^{\mathrm{h}} \mathrm{LH}$ : luteinizing hormone.

${ }^{\mathrm{i}} \mathrm{FSH}$ : follicle stimulating hormone.

$\mathrm{j}_{\mathrm{AMH}}$ : anti-Müllerian hormone.

\section{Data Determined From Stored Samples}

Venous blood samples were drawn after overnight fasting and stored at $-80^{\circ} \mathrm{C}$ in the biobank. To assess dyslipidemia, a lipid spectrum will be measured, consisting of triglycerides, high-density lipoprotein, low-density lipoprotein, total cholesterol, and apolipoprotein-B. Insulin resistance will be assessed by measuring glucose and insulin. Additionally, adiponectin, leptin, and uric acid will be measured. Inflammatory markers include high sensitivity C-reactive protein, interleukin-6, high sensitivity tumor necrosis factor alpha, and interleukin-1. The following possible confounders will be measured: insulin-like growth factor 1, kidney function (creatinine, urea), sex hormones (luteinizing hormone, follicle stimulating hormone, anti-Müllerian hormone in women, estradiol in women, testosterone in men), thyroid function (thyroid-stimulating hormone, free thyroxine), cortisol.

DNA for analysis of single nucleotide polymorphisms will be isolated from blood or, in survivors who received allogeneic stem cell transplantation, saliva. Saliva was obtained by spitting into a collection tube (Oragene kit) after not drinking or eating for 30 minutes.

\section{Metabolic Syndrome Definition}

Metabolic syndrome will be classified according to definitions by the third Adult Treatment Panel Report of the National Cholesterol Education Program [37] and the Joint Interim Statement of the International Diabetes Federation; National Heart, Lung, and Blood Institute; and the American Heart Association [38] (Table 1). Should these criteria be updated during our analysis, we will strive to take these adjustments into account.

\section{Risk of Bias}

Sex, date of birth, date of cancer diagnosis, and disease and treatment data are also available for nonparticipating survivors. Hence, comparing participating and nonparticipating survivors in order to determine the risk of selection bias is feasible. We will also compare these data between survivors with complete and incomplete data to judge the risk of attrition bias. Neither physician nor study personnel were blinded to the exposures of the survivors. Objectively measurable outcomes will reduce the risk of bias in this setting.

\section{Statistical Analysis}

\section{Prevalence of Metabolic Syndrome}

The percentage of subjects with metabolic syndrome and the separate components will be assessed in survivors and in the Lifelines reference cohort according to both aforementioned metabolic syndrome definitions. Both cohorts will be compared by Chi-square (or Fisher exact) test. The relative risk for survivors to develop metabolic syndrome, compared to Lifelines reference data, will be calculated by employing a log-binomial regression model. The agreement between both metabolic syndrome definitions will be investigated with kappa statistic, in the whole cohort and stratified by sex.

A total body fat percentage of more than two standard deviations above the mean, as assessed by dual-energy x-ray absorptiometry, will be used as the most reliable marker for adiposity. We will estimate the correlation between waist circumference and fat percentage measured by dual-energy $\mathrm{x}$-ray absorptiometry scan, and we will compare overweight classification with both definitions.

\section{Risk Factors}

Treatment-related risk factors for occurrence of metabolic syndrome and the separate components will be assessed using multiple uni- and multivariable logistic regression models. Based on literature, an initial model will be built with cranial radiotherapy, abdominal radiotherapy, and alkylating agents (total alkylating dose calculated using cyclophosphamide equivalent dose [61]) as treatment-related independent variables, and age, sex, follow-up time, and smoking as patient-related independent variables. The effect of potential additional risk factors will be assessed by adding them to the initial model, and variables with a $P$ value $<.20$ will be kept in the final model. These potential risk factors include all other chemotherapy agents (type and total cumulative dose), other radiotherapy fields (body location and dose), corticosteroids, education level, family history, physical activity, functional exercise capacity, and comorbidities. 
We will also investigate different abdominal radiotherapy fields involved (pancreas, liver), and the influence of stem cell transplantation conditioning regimens. We will also study patient- and treatment-related risk factors for the outcome underdiagnosis of overweight measured by waist circumference.

\section{Biomarkers}

Biomarker values will be reported, with reference values from the local laboratory where the samples are measured. This will be compared to Lifelines reference data by Chi-square (or Fisher exact) test. A risk factor analysis of altered biomarker values will be performed similarly to the abovementioned strategy for risk factor analysis of metabolic syndrome occurrence.

The diagnostic and predictive value of the biomarkers to detect metabolic syndrome will be investigated in multiple steps. We will stratify the survivors by metabolic syndrome presence or absence and compare mean or median values with the $t$ test or Mann-Whitney U test. We will evaluate sensitivity and specificity and positive and negative predictive value based on the reference values of the local laboratory where the samples are measured. We will compare the area under the curve for a model with metabolic syndrome components and for a model with each biomarker added in order to investigate the additional diagnostic value of the novel biomarkers. We will build multivariable logistic regression models with metabolic syndrome as dependent variable and the biomarker as independent variable. In these models, we will also include metabolic syndrome components as covariates in order to investigate the independent predictive value of the novel biomarkers. We will estimate the metabolic syndrome risk by including the biomarker as categorical as well as continuous variable.

Correlation (Pearson or Spearman) between biomarkers and fat percentage by dual-energy $\mathrm{x}$-ray absorptiometry scan will be used to measure the potential use as surrogate markers for adiposity.

\section{Genetic Susceptibility Analysis}

Genotyping will be performed with the Infinium Global Screening Array [62] on DNA isolated from blood or, in post-stem cell transplantation survivors, saliva. Quality control of the genotype data will be performed following a standardized protocol [63] including filtering based on call rate (excluded when $<0.975$ for either single nucleotide polymorphism or individual call rate), Hardy-Weinberg equilibrium, excess heterozygosity, gender mismatches, and familial relationships. Genetic ancestry will be assessed based on principal component analysis. Imputation will be performed with the Michigan Imputation Server using standard settings [64] with reference panel Haplotype Reference Consortium version r1.1 [65].

The single nucleotide polymorphism analysis will be performed with the RVtests software package [66] using multiple logistic regression models with metabolic syndrome and its separate components as outcomes. The initial analysis will be adjusted for age at follow-up, sex, and genetic ancestry. Then, potentially relevant covariates will be added to the model using forward selection to study whether they influence the single nucleotide polymorphism analysis; if so, they will be kept in the model.
These covariates include: body mass index at follow-up, comorbidities (growth hormone deficiency, hypogonadism, diabetes mellitus, and hypothyroidism), cranial and abdominal radiotherapy, and alkylating agents (cyclophosphamide equivalent dose). We will also perform a time-to-event analysis (with left-censoring) on identified hits in order to get clinically relevant effect estimates.

Quality control of the single nucleotide polymorphism analysis will be performed with the EasyQC package using standard settings [67]. This includes filtering based on minor allele frequency (excluded when <0.05) and imputation quality (excluded when $<0.3$ ).

Visualization of the genetic associations and annotation of biological function for the top single nucleotide polymorphisms will be performed with the FUMA platform [68]. Findings will be replicated in available independent international cohorts.

\section{Results}

\section{Patient Accrual}

Patient accrual started in 2016 and lasted until April 2020. A total of 2380/4741 survivors have participated (participation rate 50.2\%). From July 2020, biomarker testing, single nucleotide polymorphism analysis, and data analysis will be performed.

\section{Power Calculation}

We performed a power calculation with an expected prevalence of metabolic syndrome in our study cohort of 30\%. This percentage is based on results from the SJLIFE cohort, in which the prevalence of clinically diagnosed metabolic syndrome in 1598 survivors, after a mean of 25.6 years since diagnosis, was $31.8 \%$ [6]. This is the only large cohort study so far with clinically diagnosed metabolic syndrome in survivors of heterogeneous malignancies with a follow-up time comparable to that of our cohort.

Based on the sample size of 2380 survivors, expected metabolic syndrome prevalence of $30 \%$, power of $80 \%$, and type I error of .05 , we will have sufficient power to detect an approximate $3 \%$ difference in metabolic syndrome prevalence with the reference cohort. For risk factor analysis among survivors, the minimum detectable difference will depend on in how many survivors the risk factor (eg, treatment regimen) is present. For example, if the risk factor is present in $10 \%, 25 \%$, or $50 \%$ of survivors, a minimum difference of approximately $9 \%, 7 \%$, or $6 \%$, respectively, can be detected.

A genetic power calculator was used to estimate the relative risk that can be found in the genetic susceptibility analysis for an assumed minor allele frequency of 0.25 [69]. Based on the sample size of 2380, metabolic syndrome population prevalence of $15 \%$ [70], a power of $80 \%$, a type I error of $5 \times 10^{-8}$, and a case-control ratio of $1: 2$, the relative risk per high risk allele that can be found is 1.5 . 


\section{Discussion}

In the current study, we will assess the prevalence and patientand treatment-related risk factors for metabolic syndrome and its separate components in adult survivors of childhood cancer, as well as the additional diagnostic value of novel biomarkers for surveillance, and the genetic susceptibility to (treatment-related) metabolic syndrome by single nucleotide polymorphism analysis.

A total of 2380 survivors have participated in the study. This corresponds to $38.6 \%$ of all survivors $(\mathrm{N}=6165)$ in the Dutch LATER cohort, and a participation rate of $50.2 \%$ of invited adult survivors $(n=4741)$. The definitive numbers of refusals, nonresponders, deaths or otherwise excluded subjects are not available yet. We will report these in the paper with the results of our study.

Strengths of this study include the availability of a national cohort of survivors, the availability of comprehensive disease and treatment data, and the clinical assessment of late effects, in addition to questionnaire based endpoints. So far, the role of biomarkers and genetic susceptibility to metabolic syndrome has not been well defined in survivors. We specifically intend to use dual-energy $\mathrm{x}$-ray absorptiometry scans and relevant biomarkers (those with a high independent diagnostic or prognostic value, and a high correlation with fat percentage on dual-energy $\mathrm{x}$-ray absorptiometry scan) to enable identification of survivors at risk for metabolic syndrome, in whom waist circumference measurement is not feasible due to abdominal radiotherapy.

In conclusion, our study will provide knowledge on clinical and genetic determinants of metabolic syndrome and the diagnostic value of biomarkers in adult childhood cancer survivors. The results of this study will be used to optimize surveillance guidelines for metabolic syndrome among survivors, based on enhanced risk stratification and screening strategies. This will improve the diagnosis of metabolic syndrome and prevent complications, thereby improving quality of life.

\section{Conflicts of Interest}

None declared.

\section{References}

1. de Haas E, Oosting SF, Lefrandt JD, Wolffenbuttel BH, Sleijfer DT, Gietema JA. The metabolic syndrome in cancer survivors. The Lancet Oncology 2010 Feb;11(2):193-203. [doi: 10.1016/S1470-2045(09)70287-6] [Medline: 20152771]

2. Rosen GP, Nguyen H, Shaibi GQ. Metabolic syndrome in pediatric cancer survivors: a mechanistic review. Pediatr Blood Cancer 2013 Dec;60(12):1922-1928. [doi: 10.1002/pbc.24703] [Medline: 23913590]

3. Pluimakers VG, van Waas M, Neggers SJCMM, van den Heuvel-Eibrink MM. Metabolic syndrome as cardiovascular risk factor in childhood cancer survivors. Crit Rev Oncol Hematol 2019 Jan;133:129-141. [doi: 10.1016/j.critrevonc.2018.10.010] [Medline: $\underline{30661649}$ ]

4. Reaven GM. Banting lecture 1988. Role of insulin resistance in human disease. Diabetes 1988 Dec;37(12):1595-1607. [doi: 10.2337/diab.37.12.1595] [Medline: $\underline{\text { 3056758] }}$

5. DeFronzo RA, Ferrannini E. Insulin resistance. A multifaceted syndrome responsible for NIDDM, obesity, hypertension, dyslipidemia, and atherosclerotic cardiovascular disease. Diabetes Care 1991 Mar;14(3):173-194. [doi: 10.2337/diacare.14.3.173] [Medline: 2044434]

6. Smith WA, Li C, Nottage KA, Mulrooney DA, Armstrong GT, Lanctot JQ, et al. Lifestyle and metabolic syndrome in adult survivors of childhood cancer: a report from the St. Jude Lifetime Cohort Study. Cancer 2014 Sep 01;120(17):2742-2750 [FREE Full text] [doi: 10.1002/cncr.28670] [Medline: 25070001]

7. Nottage KA, Ness KK, Li C, Srivastava D, Robison LL, Hudson MM. Metabolic syndrome and cardiovascular risk among long-term survivors of acute lymphoblastic leukaemia - From the St. Jude Lifetime Cohort. Br J Haematol 2014 May;165(3):364-374 [FREE Full text] [doi: 10.1111/bjh.12754] [Medline: 24467690]

8. van der Pal HJ, van Dalen EC, van Delden E, van Dijk IW, Kok WE, Geskus RB, et al. High risk of symptomatic cardiac events in childhood cancer survivors. J Clin Oncol 2012 May 01;30(13):1429-1437. [doi: 10.1200/JCO.2010.33.4730] [Medline: 22473161]

9. Brouwer CAJ, Postma A, Hooimeijer HLH, Smit AJ, Vonk JM, van Roon AM, et al. Endothelial damage in long-term survivors of childhood cancer. J Clin Oncol 2013 Nov 01;31(31):3906-3913. [doi: 10.1200/JCO.2012.46.6086] [Medline: 24062395]

10. Reulen RC, Winter DL, Frobisher C, Lancashire ER, Stiller CA, Jenney ME, British Childhood Cancer Survivor Study Steering Group. Long-term cause-specific mortality among survivors of childhood cancer. JAMA 2010 Jul 14;304(2):172-179. [doi: 10.1001/jama.2010.923] [Medline: 20628130]

11. Schindler M, Spycher BD, Ammann RA, Ansari M, Michel G, Kuehni CE, Swiss Paediatric Oncology Group (SPOG). Cause-specific long-term mortality in survivors of childhood cancer in Switzerland: A population-based study. Int J Cancer 2016 Jul 15;139(2):322-333 [FREE Full text] [doi: 10.1002/ijc.30080] [Medline: 26950898]

12. Armstrong GT, Liu Q, Yasui Y, Neglia JP, Leisenring W, Robison LL, et al. Late mortality among 5-year survivors of childhood cancer: a summary from the Childhood Cancer Survivor Study. J Clin Oncol 2009 May 10;27(14):2328-2338 [FREE Full text] [doi: 10.1200/JCO.2008.21.1425] [Medline: 19332714] 
13. Bagnasco F, Caruso S, Andreano A, Valsecchi MG, Jankovic M, Biondi A, OTR-AIEOP Registry. Late mortality and causes of death among 5-year survivors of childhood cancer diagnosed in the period 1960-1999 and registered in the Italian Off-Therapy Registry. Eur J Cancer 2019 Mar;110:86-97. [doi: 10.1016/j.ejca.2018.12.021] [Medline: $\underline{30772657]}$

14. Chemaitilly W, Cohen LE. Diagnosis of endocrine disease: Endocrine late-effects of childhood cancer and its treatments. Eur J Endocrinol 2017 Apr;176(4):R183-R203. [doi: 10.1530/EJE-17-0054] [Medline: 28153840]

15. Friedman DN, Hilden P, Moskowitz CS, Suzuki M, Boulad F, Kernan NA, et al. Cardiovascular Risk Factors in Survivors of Childhood Hematopoietic Cell Transplantation Treated with Total Body Irradiation: A Longitudinal Analysis. Biol Blood Marrow Transplant 2017 Mar;23(3):475-482 [FREE Full text] [doi: 10.1016/j.bbmt.2016.12.623] [Medline: 28040534]

16. de Vathaire F, El-Fayech C, Ben Ayed FF, Haddy N, Guibout C, Winter D, et al. Radiation dose to the pancreas and risk of diabetes mellitus in childhood cancer survivors: a retrospective cohort study. Lancet Oncol 2012 Oct;13(10):1002-1010. [doi: 10.1016/S1470-2045(12)70323-6] [Medline: 22921663]

17. Wei C, Thyagiarajan M, Hunt L, Cox R, Bradley K, Elson R, et al. Reduced beta-cell reserve and pancreatic volume in survivors of childhood acute lymphoblastic leukaemia treated with bone marrow transplantation and total body irradiation. Clin Endocrinol (Oxf) 2015 Jan;82(1):59-67. [doi: 10.1111/cen.12575] [Medline: 25132503]

18. van Dorp W, Blijdorp K, Laven JSE, Pieters R, Visser JA, van der Lely AJ, et al. Decreased ovarian function is associated with obesity in very long-term female survivors of childhood cancer. Eur J Endocrinol 2013 Jun;168(6):905-912. [doi:

10.1530/EJE-13-0114] [Medline: 23557987]

19. de Haas EC, Altena R, Boezen HM, Zwart N, Smit AJ, Bakker SJL, et al. Early development of the metabolic syndrome after chemotherapy for testicular cancer. Ann Oncol 2013 Mar;24(3):749-755 [FREE Full text] [doi: 10.1093/annonc/mds527] [Medline: 23131388]

20. Darzy K, Shalet S. Hypopituitarism following Radiotherapy Revisited. Endocr Dev 2009;15:1-24. [doi: 10.1159/000207607] [Medline: 19293601]

21. van Waas M, Neggers SJCMM, Raat H, van Rij CM, Pieters R, van den Heuvel-Eibrink MM. Abdominal radiotherapy: a major determinant of metabolic syndrome in nephroblastoma and neuroblastoma survivors. PLoS One 2012;7(12):e52237 [FREE Full text] [doi: 10.1371/journal.pone.0052237] [Medline: 23251703]

22. Mostoufi-Moab S, Seidel K, Leisenring WM, Armstrong GT, Oeffinger KC, Stovall M, et al. Endocrine Abnormalities in Aging Survivors of Childhood Cancer: A Report From the Childhood Cancer Survivor Study. J Clin Oncol 2016 Sep 20;34(27):3240-3247 [FREE Full text] [doi: 10.1200/JCO.2016.66.6545] [Medline: 27382091]

23. Belle FN, Weiss A, Schindler M, Goutaki M, Bochud M, Zimmermann K, et al. Overweight in childhood cancer survivors: the Swiss Childhood Cancer Survivor Study. Am J Clin Nutr 2018 Jan 01;107(1):3-11. [doi: 10.1093/ajen/nqx006] [Medline: 29381792]

24. Wilson CL, Liu W, Yang JJ, Kang G, Ojha RP, Neale GA, et al. Genetic and clinical factors associated with obesity among adult survivors of childhood cancer: A report from the St. Jude Lifetime Cohort. Cancer 2015 Jul 01;121(13):2262-2270 [FREE Full text] [doi: 10.1002/cncr.29153] [Medline: 25963547]

25. van Santen HM, Geskus RB, Raemaekers S, van Trotsenburg ASP, Vulsma T, van der Pal HJH, et al. Changes in body mass index in long-term childhood cancer survivors. Cancer 2015 Dec 01;121(23):4197-4204 [FREE Full text] [doi: 10.1002/cncr.29614] [Medline: 26287726]

26. Meacham LR, Sklar CA, Li S, Liu Q, Gimpel N, Yasui Y, et al. Diabetes mellitus in long-term survivors of childhood cancer. Increased risk associated with radiation therapy: a report for the childhood cancer survivor study. Arch Intern Med 2009 Aug 10;169(15):1381-1388 [FREE Full text] [doi: 10.1001/archinternmed.2009.209] [Medline: 19667301]

27. Felicetti F, D'Ascenzo F, Moretti C, Corrias A, Omedè P, Marra WG, et al. Prevalence of cardiovascular risk factors in long-term survivors of childhood cancer: 16 years follow up from a prospective registry. Eur J Prev Cardiol 2015 Jun;22(6):762-770. [doi: 10.1177/2047487314529348] [Medline: 24691151]

28. Kooijmans EC, Bökenkamp A, Tjahjadi NS, Tettero JM, van Dulmen-den Broeder E, van der Pal HJ, et al. Early and late adverse renal effects after potentially nephrotoxic treatment for childhood cancer. Cochrane Database Syst Rev 2019 Mar 11;3:CD008944 [FREE Full text] [doi: 10.1002/14651858.CD008944.pub3] [Medline: 30855726]

29. Gibson TM, Li Z, Green DM, Armstrong GT, Mulrooney DA, Srivastava D, et al. Blood Pressure Status in Adult Survivors of Childhood Cancer: A Report from the St. Jude Lifetime Cohort Study. Cancer Epidemiol Biomarkers Prev 2017 Dec;26(12):1705-1713 [FREE Full text] [doi: 10.1158/1055-9965.EPI-17-0510] [Medline: 29167278]

30. van Waas M, Neggers SJCMM, van Eck JP, van Noesel MM, van der Lely A, de Jong FH, et al. Adrenal function in adult long-term survivors of nephroblastoma and neuroblastoma. Eur J Cancer 2012 May;48(8):1159-1166 [FREE Full text] [doi: 10.1016/j.ejca.2012.02.046] [Medline: 22513228]

31. Oudin C, Simeoni M, Sirvent N, Contet A, Begu-Le Coroller A, Bordigoni P, et al. Prevalence and risk factors of the metabolic syndrome in adult survivors of childhood leukemia. Blood 2011 Apr 28;117(17):4442-4448. [doi: 10.1182/blood-2010-09-304899] [Medline: 21278355]

32. Chow EJ, Simmons JH, Roth CL, Baker KS, Hoffmeister PA, Sanders JE, et al. Increased cardiometabolic traits in pediatric survivors of acute lymphoblastic leukemia treated with total body irradiation. Biol Blood Marrow Transplant 2010 Dec;16(12):1674-1681 [FREE Full text] [doi: 10.1016/j.bbmt.2010.05.016] [Medline: 20685399] 
33. Clemens E, van der Kooi ALF, Broer L, van Dulmen-den Broeder E, Visscher H, Kremer L, et al. The influence of genetic variation on late toxicities in childhood cancer survivors: A review. Crit Rev Oncol Hematol 2018 Jun;126:154-167 [FREE Full text] [doi: 10.1016/j.critrevonc.2018.04.001] [Medline: 29759558]

34. Gramatges MM, Bhatia S. Evidence for Genetic Risk Contributing to Long-Term Adverse Treatment Effects in Childhood Cancer Survivors. Annu Rev Med 2018 Jan 29;69:247-262. [doi: 10.1146/annurev-med-041916-124328] [Medline: 29029584]

35. van Waas M, Neggers SJCMM, Uitterlinden AG, Blijdorp K, van der Geest IMM, Pieters R, et al. Treatment factors rather than genetic variation determine metabolic syndrome in childhood cancer survivors. Eur J Cancer 2013 Feb;49(3):668-675. [doi: 10.1016/j.ejca.2012.09.007] [Medline: 23036851]

36. England J, Drouin S, Beaulieu P, St-Onge P, Krajinovic M, Laverdière C, et al. Genomic determinants of long-term cardiometabolic complications in childhood acute lymphoblastic leukemia survivors. BMC Cancer 2017 Nov 10;17(1):751 [FREE Full text] [doi: 10.1186/s12885-017-3722-6] [Medline: 29126409]

37. National Cholesterol Education Program (NCEP) Expert Panel on Detection, Evaluation, and Treatment of High Blood Cholesterol in Adults (Adult Treatment Panel III). Third Report of the National Cholesterol Education Program (NCEP) Expert Panel on Detection, Evaluation, and Treatment of High Blood Cholesterol in Adults (Adult Treatment Panel III) Final Report. Circulation 2002 Dec 17;106(25):3143-3143. [doi: 10.1161/circ.106.25.3143]

38. Alberti KGMM, Eckel RH, Grundy SM, Zimmet PZ, Cleeman JI, Donato KA, International Diabetes Federation Task Force on EpidemiologyPrevention, Hational Heart, Lung,Blood Institute, American Heart Association, World Heart Federation, International Atherosclerosis Society, International Association for the Study of Obesity. Harmonizing the metabolic syndrome: a joint interim statement of the International Diabetes Federation Task Force on Epidemiology and Prevention; National Heart, Lung, and Blood Institute; American Heart Association; World Heart Federation; International Atherosclerosis Society; and International Association for the Study of Obesity. Circulation 2009 Oct 20;120(16):1640-1645 [FREE Full text] [doi: 10.1161/CIRCULATIONAHA.109.192644] [Medline: 19805654]

39. Koh KK, Han SH, Quon MJ. Inflammatory markers and the metabolic syndrome: insights from therapeutic interventions. J Am Coll Cardiol 2005 Dec 06;46(11):1978-1985 [FREE Full text] [doi: 10.1016/j.jacc.2005.06.082] [Medline: 16325028]

40. Kanbay M, Jensen T, Solak Y, Le M, Roncal-Jimenez C, Rivard C, et al. Uric acid in metabolic syndrome: From an innocent bystander to a central player. Eur J Intern Med 2016 Apr;29:3-8 [FREE Full text] [doi: 10.1016/j.ejim.2015.11.026] [Medline: 26703429]

41. Blijdorp K, van den Heuvel-Eibrink MM, Pieters R, Boot AM, Delhanty PJD, van der Lely A, et al. Obesity is underestimated using body mass index and waist-hip ratio in long-term adult survivors of childhood cancer. PLoS One 2012;7(8):e43269 [FREE Full text] [doi: 10.1371/journal.pone.0043269] [Medline: 22905245]

42. Karlage RE, Wilson CL, Zhang N, Kaste S, Green DM, Armstrong GT, et al. Validity of anthropometric measurements for characterizing obesity among adult survivors of childhood cancer: A report from the St. Jude Lifetime Cohort Study. Cancer 2015 Jun 15;121(12):2036-2043 [FREE Full text] [doi: 10.1002/cncr.29300] [Medline: 25728221]

43. Inaba H, Yang J, Kaste SC, Hartford CM, Motosue MS, Chemaitilly W, et al. Longitudinal changes in body mass and composition in survivors of childhood hematologic malignancies after allogeneic hematopoietic stem-cell transplantation. J Clin Oncol 2012 Nov 10;30(32):3991-3997 [FREE Full text] [doi: 10.1200/JCO.2011.40.0457] [Medline: 23032628]

44. Wei C, Thyagiarajan MS, Hunt LP, Shield JPH, Stevens MCG, Crowne EC. Reduced insulin sensitivity in childhood survivors of haematopoietic stem cell transplantation is associated with lipodystropic and sarcopenic phenotypes. Pediatr Blood Cancer 2015 Nov;62(11):1992-1999. [doi: 10.1002/pbc.25601] [Medline: 25989749]

45. Parish S, Offer A, Clarke R, Hopewell JC, Hill MR, Otvos JD, Heart Protection Study Collaborative Group. Lipids and lipoproteins and risk of different vascular events in the MRC/BHF Heart Protection Study. Circulation 2012 May 22;125(20):2469-2478. [doi: 10.1161/CIRCULATIONAHA.111.073684] [Medline: 22539783]

46. Mach F, Baigent C, Catapano AL, Koskinas KC, Casula M, Badimon L, ESC Scientific Document Group. 2019 ESC/EAS Guidelines for the management of dyslipidaemias: lipid modification to reduce cardiovascular risk. Eur Heart J 2020 Jan 01;41(1):111-188. [doi: 10.1093/eurheartj/ehz455] [Medline: 31504418]

47. Ketterl TG, Chow EJ, Leisenring WM, Goodman P, Koves IH, Petryk A, et al. Adipokines, Inflammation, and Adiposity in Hematopoietic Cell Transplantation Survivors. Biol Blood Marrow Transplant 2018 Mar;24(3):622-626 [FREE Full text] [doi: 10.1016/j.bbmt.2017.11.024] [Medline: 29197678]

48. Skoczen S, Tomasik PJ, Bik-Multanowski M, Surmiak M, Balwierz W, Pietrzyk JJ, et al. Plasma levels of leptin and soluble leptin receptor and polymorphisms of leptin gene -18G > A and leptin receptor genes K109R and Q223R, in survivors of childhood acute lymphoblastic leukemia. J Exp Clin Cancer Res 2011 Jun 01;30:64 [FREE Full text] [doi: 10.1186/1756-9966-30-64] [Medline: 21631924]

49. Im J, Kim S, Lee J, Shim J, Lee H, Lee D. Association between hypoadiponectinemia and cardiovascular risk factors in nonobese healthy adults. Metabolism 2006 Nov;55(11):1546-1550. [doi: 10.1016/j.metabol.2006.06.027] [Medline: 17046559]

50. Cicero AFG, Fogacci F, Giovannini M, Grandi E, Rosticci M, D'Addato S, et al. Serum uric acid predicts incident metabolic syndrome in the elderly in an analysis of the Brisighella Heart Study. Sci Rep 2018 Aug 01;8(1):11529 [FREE Full text] [doi: 10.1038/s41598-018-29955-w] [Medline: 30068918] 
51. Saultier P, Auquier P, Bertrand Y, Vercasson C, Oudin C, Contet A, et al. Metabolic syndrome in long-term survivors of childhood acute leukemia treated without hematopoietic stem cell transplantation: an L.E.A. study. Haematologica 2016 Dec;101(12):1603-1610 [FREE Full text] [doi: 10.3324/haematol.2016.148908] [Medline: 27515247]

52. Oudin C, Auquier P, Bertrand Y, Contet A, Kanold J, Sirvent N, et al. Metabolic syndrome in adults who received hematopoietic stem cell transplantation for acute childhood leukemia: an LEA study. Bone Marrow Transplant 2015 Nov;50(11):1438-1444. [doi: 10.1038/bmt.2015.167] [Medline: 26191949]

53. Holmqvist AS, Olsen JH, Andersen KK, de Fine Licht S, Hjorth L, Garwicz S, ALiCCS study group. Adult life after childhood cancer in Scandinavia: diabetes mellitus following treatment for cancer in childhood. Eur J Cancer 2014 Apr;50(6):1169-1175. [doi: 10.1016/j.ejca.2014.01.014] [Medline: 24507548]

54. Bhakta N, Liu Q, Ness KK, Baassiri M, Eissa H, Yeo F, et al. The cumulative burden of surviving childhood cancer: an initial report from the St Jude Lifetime Cohort Study (SJLIFE). The Lancet 2017 Dec 09;390(10112):2569-2582 [FREE Full text] [doi: 10.1016/S0140-6736(17)31610-0] [Medline: 28890157]

55. Prasad M, Arora B, Chinnaswamy G, Vora T, Narula G, Banavali S, et al. Nutritional status in survivors of childhood cancer: Experience from Tata Memorial Hospital, Mumbai. Indian J Cancer 2015;52(2):219-223 [FREE Full text] [doi: 10.4103/0019-509X.175814] [Medline: 26853412]

56. Steliarova-Foucher E, Stiller C, Lacour B, Kaatsch P. International Classification of Childhood Cancer, third edition. Cancer 2005 Apr 01;103(7):1457-1467 [FREE Full text] [doi: 10.1002/cncr.20910] [Medline: 15712273]

57. Lifelines cohort and biobank. Lifelines. URL: https://www.lifelines.nl/ [accessed 2020-05-01]

58. Wendel-Vos GCW, Schuit AJ, Saris WHM, Kromhout D. Reproducibility and relative validity of the short questionnaire to assess health-enhancing physical activity. J Clin Epidemiol 2003 Dec;56(12):1163-1169. [doi: 10.1016/s0895-4356(03)00220-8] [Medline: 14680666]

59. ATS Committee on Proficiency Standards for Clinical Pulmonary Function Laboratories. ATS statement: guidelines for the six-minute walk test. Am J Respir Crit Care Med 2002 Jul 01;166(1):111-117. [doi: 10.1164/ajrccm.166.1.at1102] [Medline: 12091180]

60. Casanova C, Celli BR, Barria P, Casas A, Cote C, de Torres JP, Six Minute Walk Distance Project (ALAT). The 6-min walk distance in healthy subjects: reference standards from seven countries. Eur Respir J 2011 Jan;37(1):150-156 [FREE Full text] [doi: 10.1183/09031936.00194909] [Medline: 20525717]

61. Green DM, Nolan VG, Goodman PJ, Whitton JA, Srivastava D, Leisenring WM, et al. The cyclophosphamide equivalent dose as an approach for quantifying alkylating agent exposure: a report from the Childhood Cancer Survivor Study. Pediatr Blood Cancer 2014 Jan;61(1):53-67 [FREE Full text] [doi: 10.1002/pbc.24679] [Medline: 23940101]

62. Illumina. Infinium Global Screening Array-24 v3.0. BeadChip. 2020. URL: https://www.illumina.com/products/by-type/ microarray-kits/infinium-global-screening.html [accessed 2020-05-01]

63. Anderson CA, Pettersson FH, Clarke GM, Cardon LR, Morris AP, Zondervan KT. Data quality control in genetic case-control association studies. Nat Protoc 2010 Sep;5(9):1564-1573 [FREE Full text] [doi: 10.1038/nprot.2010.116] [Medline: 21085122]

64. Das S, Forer L, Schönherr S, Sidore C, Locke AE, Kwong A, et al. Next-generation genotype imputation service and methods. Nat Genet 2016 Oct;48(10):1284-1287 [FREE Full text] [doi: 10.1038/ng.3656] [Medline: 27571263]

65. McCarthy S, Das S, Kretzschmar W, Delaneau O, Wood AR, Teumer A, Haplotype Reference Consortium. A reference panel of 64,976 haplotypes for genotype imputation. Nat Genet 2016 Oct;48(10):1279-1283 [FREE Full text] [doi: 10.1038/ng.3643] [Medline: 27548312]

66. Zhan X, Hu Y, Li B, Abecasis GR, Liu DJ. RVTESTS: an efficient and comprehensive tool for rare variant association analysis using sequence data. Bioinformatics 2016 May 01;32(9):1423-1426 [FREE Full text] [doi: 10.1093/bioinformatics/btw079] [Medline: 27153000]

67. Heid I, Winkler T, Gorski M, Olden M. Easy QC. Universität Regensburg. URL: https://www.uni-regensburg.de/medizin/ epidemiologie-praeventivmedizin/genetische-epidemiologie/software/ [accessed 2020-05-01]

68. Watanabe K, Taskesen E, van Bochoven A, Posthuma D. Functional mapping and annotation of genetic associations with FUMA. Nat Commun 2017 Nov 28;8(1):1826 [FRE Full text] [doi: 10.1038/s41467-017-01261-5] [Medline: 29184056]

69. Purcell S, Cherny SS, Sham PC. Genetic Power Calculator: design of linkage and association genetic mapping studies of complex traits. Bioinformatics 2003 Jan;19(1):149-150. [doi: 10.1093/bioinformatics/19.1.149] [Medline: 12499305]

70. Blokstra A, Vissink P, Venmans L, Holleman P, van DSY, Smit H, et al. Measuring The Netherlands. A monitoring study of risk factors in the general population-2010. RIVM Rapport 260152001/ 2009:2011. 
Edited by $G$ Eysenbach; submitted 09.06.20; peer-reviewed by $N$ Waespe; comments to author 04.07.20; revised version received 18.08.20; accepted 10.11.20; published 27.01.21

Please cite as:

Pluimakers V, Fiocco M, van Atteveld J, Hobbelink M, Bresters D, Van Dulmen-den Broeder E, Van der Heiden-van der Loo M, Janssens GO, Kremer L, Loonen J, Louwerens M, Van der Pal H, Ronckers C, Van Santen H, Versluys B, De Vries A, Van den Heuvel-Eibrink $M$, Neggers $S$

Metabolic Syndrome Parameters, Determinants, and Biomarkers in Adult Survivors of Childhood Cancer: Protocol for the Dutch Childhood Cancer Survivor Study on Metabolic Syndrome (Dutch LATER METS)

JMIR Res Protoc 2021;10(1):e21256

URL: https://www.researchprotocols.org/2021/1/e21256

doi: $10.2196 / 21256$

PMID: $\underline{32750002}$

(C) Vincent Pluimakers, Marta Fiocco, Jenneke van Atteveld, Monique Hobbelink, Dorine Bresters, Eline Van Dulmen-den Broeder, Margriet Van der Heiden-van der Loo, Geert O Janssens, Leontien Kremer, Jacqueline Loonen, Marloes Louwerens, Helena Van der Pal, Cécile Ronckers, Hanneke Van Santen, Birgitta Versluys, Andrica De Vries, Marry Van den Heuvel-Eibrink, Sebastian Neggers. Originally published in JMIR Research Protocols (http://www.researchprotocols.org), 27.01.2021. This is an open-access article distributed under the terms of the Creative Commons Attribution License (https://creativecommons.org/licenses/by/4.0/), which permits unrestricted use, distribution, and reproduction in any medium, provided the original work, first published in JMIR Research Protocols, is properly cited. The complete bibliographic information, a link to the original publication on http://www.researchprotocols.org, as well as this copyright and license information must be included. 